\title{
PENGARUH CARBON BLACK PADA PEMBUATAN
PLASTIK UNTUK PLASTIK UNTUK IRIGASI SISTEM TETES
}

\author{
Arum Yuniari' ${ }^{1}$, Dwi Wahini Nurhayati'), Niken Karsiati"
}

\section{INTISARI}

Penelitian ini bertujuan untuk mengetahui pengaruh carb ın black pada pembuatan plastik untuk irigasi sistem tetes. Plastik tebal $2 \mathrm{~mm}$ dibuat dari low density polyethylene (LDPE), high density polyethylene (HDPE) dan carbon black menggunakan mesin blown film pada kondisi proses yang tetap. Carbon black yang digunakan adalah $0 ; 2,5 ; 5 ; 7,5 ; 10 \mathrm{phr}$ dan ratio LDPE/HDPE adalah $0 / 100,50 / 50,100 / 0 \mathrm{phr}$. Sifat fisis menunjukkan bahwa kenaikan carbon black menurunkan kuat tarik, kemuluran, kuat sobek dan kerapuhan. Formulasi terbaik terdiri dari HDPE $100 \mathrm{phr}$ dan carbon black $10 \mathrm{phr}$, dengan sifat fisis sebagai berikut : kuat tarik $158 \mathrm{~kg} / \mathrm{cm}^{2}$, kemuluran $140 \%$
dan kuat sobek $91,46 \mathrm{~kg} / \mathrm{cm}^{2}$.

\begin{abstract}
The objective of this experiment was to know the influence carbon black was added to the plastics for drip irrigation systems. Plastics of $0,2 \mathrm{~mm}$ thickness for drip irrigation system was made from mixing of low density polyethylene (LDPE), high density polyethylene (HDPE) and carbon black by a blown film machine on the fixed processing condition. The investigated carbon 100/0 respectivere $0 ; 2,5 ; 5 ; 7,5$ and $10 \mathrm{phr}$ respectively and LDPE/HDPE ratio were 0/100,50/50, tensile strength, elongation at break, tear strest showed and increasing of carbon black decreasing of HDPE 100 phr and carbon black $10 \mathrm{phr}$, with the physicn! pr. The best formulation was consist $158 \mathrm{~kg} / \mathrm{cm}^{2}$. elongation at break $140 \%$, and tear strength $91,46 \mathrm{~kg} / \mathrm{cm}^{2}$.
\end{abstract}

\section{PENDAHULUAN}

Di Daerah Istimewa Yogyakarta, khususnya di Kabupaten Gunung Kidul masih terdapat lahan kering yang dapat di manfaatkan untuk lahan pertanian. Ketersediaan air pada lahan kering sangat terbatas jumlahnya, maka penggunaan air harus dilakukan sehemat mungkin. Salah satu upaya and Phene (1987) irigasi tetes adalah sirtadah dengan metode irigasi sistem tetes. Menurut Phene cara langsung di daerah perakaran tanaman pemberian air untuk tanaman dimana air diberikan sedari irigasi sistem tetes adalah kemampuannyan perlahan-lahan. Keuntungan yang terpenting kehilangan air permukaan dan sub permuknya untuk menyediakan kebutuhan air tanaman tanpa permukaan yang konvensional. $\mathrm{Di}$.ndmukaan yang besar yang sering dihubungkan dengan irigasi ada perusahaan pembuatannya. Pada penelitian inde ini belum banyak dipergunakan karena belum tem tetes menggunakan bahan baku politian ini direncanakan membuat plastik untuk irigasi sisdensity polyethylene (LDPE), serta polimer organik high density polyethylene (HDPE) dan low paling lunak dan kristalinitasnya paling kengisi carbon black. Low density polyethylene yang polyethylene mempunyai kombinasi sifat yang serta struktur molekulnya bercabang. Low density serta mempunyai daya serap terhadap air rendan. Sedu liat, ketahanan pukul tinggi, mudah diproses sifat derajat kristalinitasnya tinggi, keras dan tah. Sedangkan high density polyethylene mempunyai carbon black sebagai bahan pengisi organik dalam penelitian ini (Brydson 1996). Pemakaian penurunan kualitas produk karena adanya perubahan

"Balai Besar Penelitian dan Pengembangan Industri Barang Kulit, Karet dan Plastik. Yogyakarta. 
Menurut Katz dan Milewski (1978) carbon black mempunyai keunggulan lebih mudah terdispersi. Struktur molekul dan ukuran partikel carbon black berpengaruh sangat nyata terhadap sifat reologi polimer, yaitu makin kecil ukuran partikel atau makin besar strukturnya maka viskositas akan naik, hal ini menyebabkan sifat kekerasan dan kuat tariknya bertambah. Plastik untuk irigasi sistem tetes dapat diproses dengan tekuil blown film dan proses cast film, menggunakan mesin ekstrusi (Allan, 1968). Untuk mengetahui mutu dari plastik untuk irigasi sistem tetes perlu dilakukan uji fisis seperti kuat tarik, kuat sobek dan kemuluran. Sedangkan untuk mengetahui perubahan sifat fisis setelah penggunaan di lapangan dilakukan uji foto degradasi. Adapun tujuan dari penelitian ini adalah untuk mengetahui pengaruh penambahan carbon black pada plastik untuk irigasi sistem tetes serta untuk mendapatkan formulasi yang terbaik.

\section{BAHAN DAN METODA PENELITIAN}

\section{Bahan Penelitian}

Bahan baku dan bahan pembantu yang digunakan dalam penelitian ini meliputi : resin high density polyethylene (HDPE) blow molding grade; MERK Rigitex buatan PT Petro Kimia Nusantara Interindo (PENI) low density polyethylene (LDPE) blow molding grade merk Cosmothene buatan the Polyolefin Company (Singapore) Pte Ltd, asam stearat sebagai pelumas internal.

Alat penelitian terdiri atas Rheocord 90 merk Haake yang dilengkapi dengan take up unit mesin blown film, tensile strength tester merek Troning Albert type QC - II - M - 18 dan lampu ultra violet.

\section{Cara Penelitian}

1. Pembuatan plastik untuk irigasi sistem tetes

Pada pembuatan plastik untuk irigasi sistem tetes dilaksanakan dengan memvariasikan penggunaan carbon black berturut-turut $0 ; 2,5 ; 5 ; 7,5$ dan 10 bagian dengan variasi perbandingan jumlah plastik HDPE dan LDPE dari 0 ; 50 dan 100 bagian, sehingga diperoleh 15 perlakuan seperti pada tabel 1. Pada masing-masing kompon plastik ditambahkan asam stearat 5 bagian sebagai pelumas internal.

Tabel 1. Rancangan kompon plastik untuk irigasi sistem tetes dengan bahan pengisi carbon black

\begin{tabular}{|c|c|c|c|}
\hline Carbon Black (bagian) & \multicolumn{3}{|c|}{ Perbandingan bahan baku (LDPE / HDPE) bagian / bagian } \\
\cline { 2 - 4 } & $0 / 100$ & $100 / 0$ & $50 / 50$ \\
\hline 0 & I & VI & XI \\
2,5 & II & VII & XII \\
5,0 & III & VIII & XIII \\
7,5 & IV & IX & XIV \\
10 & V & X & XV \\
\hline
\end{tabular}


Bahan-bahan diatas dikomponding dengan mesin Rheocord 90, selanjutnya dibuat plastik untuk irigasi sistem tetes dengan menggunakan mesin blown film dengan lebar dan tebal tertentu. Pada kondisi operasi sebagai berikut, zone pemanasan : $100^{\circ} \mathrm{C}, 150^{\circ} \mathrm{C}$, $170^{\circ} \mathrm{C}, 190^{\circ} \mathrm{C}$ dengan putaran $60 \mathrm{rpm}$, tebal film $0,2 \mathrm{~mm}$ dengan kecepatan plastik $2.5 \mathrm{~m} /$ menit.

\section{Pengujian}

Plastik yang diperoleh akan diuji terhadap parameter mutu yang meliputi kuat tarik. kemuluran, kuat sobek sesuai SNI 19-4377-1996, Plastik Polietilen untuk mengemas. Pengujian fotodegradasi dilakukan dengan penyinaran selama 5 hari dan 10 hari. Sesudah dilakukan uji foto degradasi dilakukan uji fisis meliputi kuat tarik, kemuluran dan kuat sobek.

\section{HASIL DAN PEMBAHASAN}

Plastik untuk irigasi sistem tetes yang dibuat mempunyai bentuk seperti gambar 1 selanjutnya plastik diberi bentuk untuk mengatur lubang pengeluaran air dengan heat secting.

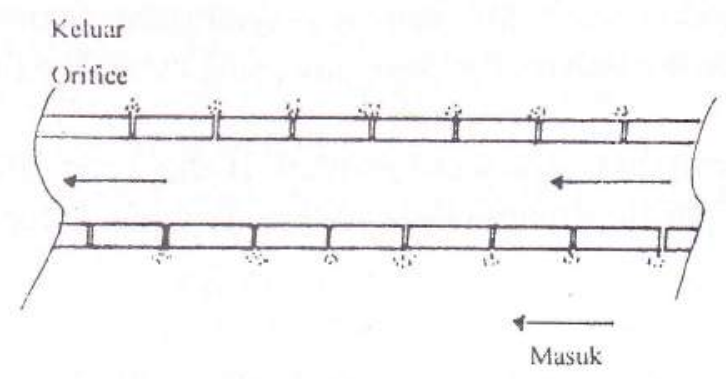

Gambar 1. Plastik untuk irigasi sistem tetes

\section{Uji Fisis}

Plastik untuk irigasi sistem tetes sebanyak 15 formulasi diuji sifat fisisnya meliputi uji kuat tarik, kemuluran, kuat sobek dan uji foto degradasi.

Tabel 2. Hasil uji kuat tarik plastik untuk irigasi sistem tetes

\begin{tabular}{|c|c|c|c|c|c|c|c|c|c|}
\hline \multirow{4}{*}{$\begin{array}{l}\text { Carbon } \\
\text { black } \\
\text { (bagian) }\end{array}$} & \multicolumn{9}{|c|}{ Kuat Tarik $(\mathrm{kg} / \mathrm{cm} 2)$} \\
\hline & \multicolumn{3}{|c|}{ LDPE/HDPE $=0 / 100$} & \multicolumn{3}{|c|}{$\mathrm{LDPE} / \mathrm{HDPE}=100 / 0$} & \multicolumn{3}{|c|}{ LDPE $/ H D P E=50 / 50$} \\
\hline & \multirow{2}{*}{$\begin{array}{l}\text { Sebelum } \\
\text { Penyinaran } \\
\text { UV }\end{array}$} & \multicolumn{2}{|c|}{$\begin{array}{c}\text { Sesudah } \\
\text { Penyinaran UV }\end{array}$} & \multirow{2}{*}{$\begin{array}{l}\text { Sebelum } \\
\text { Penyinaran } \\
\text { UV }\end{array}$} & \multicolumn{2}{|c|}{$\begin{array}{c}\text { Sesudah } \\
\text { Penyinaran UV }\end{array}$} & \multirow{2}{*}{$\begin{array}{c}\text { Sebelum } \\
\text { Penyinaran } \\
\text { UV }\end{array}$} & \multicolumn{2}{|c|}{$\begin{array}{c}\text { Sesudah } \\
\text { Penyinaran UV }\end{array}$} \\
\hline & & 5 hari & 10 hari & & 5 hari & 10 hari & & 5 hari & 10 hari \\
\hline 0 & 265,12 & 0 & 0 & 145,78 & 16,81 & 6,28 & 178,24 & 8.35 & 0 \\
\hline 2.5 & 239,39 & 0 & 0 & 138,74 & 33,60 & 9,68 & 176,43 & 28,12 & 0 \\
\hline 5,0 & 221,68 & 46,11 & 15,29 & 119,00 & 43,90 & 42,39 & 160,97 & 32,73 & 0 \\
\hline 7.5 & 216,33 & 64,97 & 54,08 & 107,93 & 47,97 & 34,54 & 157,12 & 45,52 & 0 \\
\hline 10 & 158,02 & 100,40 & 56.58 & 95,84 & 51,06 & 30,67 & 132,05 & 41,37 & () \\
\hline
\end{tabular}

Kuat tarik menurut SNI 19-4377-1996 "Plastik Polietilen untuk mengemas min 120 $\mathrm{kg} / \mathrm{cm}^{2}$.

Carbon

black

(bagian)

0

2,5

5,0

7,5

10,0

1. Tabel $1 \mathrm{~m}$ HDPE ku dari LDP dari berat maka kua hasil uji nilai kuat let selam dengan ba masih bai dengan b tarik diat diperbaik Menurut sebagai b cuaca. D plastik un HDPE da dengan mempuny dan sifat Hal ini di adherent proses or: terbentuk Plastik di setelah itı yang dital dengan b tersebut $\mathrm{t}$ sebesar 5 untuk bal pada lam HDPE 10 
Tabel. 3. Prosentase penurunan kuat tarik sesudah penyinaran dengan ultra violet

\begin{tabular}{|l|c|c|c|c|c|c|}
\hline \multirow{2}{*}{$\begin{array}{l}\text { Carbon } \\
\text { black }\end{array}$ (bagian) } & \multicolumn{6}{|c|}{$\Delta$ Kuat Tarik (\%) } \\
\cline { 2 - 7 } & \multicolumn{2}{|c|}{ LDPE/HDPE $=0 / 100$} & \multicolumn{2}{c|}{ LDPE/HDPE $=100 / 0$} & \multicolumn{2}{l|}{ LDPE/HDPE $=50 / 50$} \\
\cline { 2 - 7 } & 5 hari & 10 hari & 5 hari & 10 hari & 5 hari & 10 hari \\
\hline 0 & 100 & 100 & 88,47 & 95,69 & 95,31 & 100 \\
2,5 & 100 & 100 & 75,78 & 93,02 & 84,06 & 100 \\
5,0 & 79,20 & 93,10 & 63,11 & 64,37 & 79,67 & 100 \\
7,5 & 69,97 & 75,0 & 55,55 & 68,0 & 71,10 & 100 \\
10,0 & 36,46 & 64,20 & 46,72 & 68,0 & 68,67 & 100 \\
\hline
\end{tabular}

1. Tabel 1 menunjukkan bahwa plastik tanpa bahan pengisi (filler) carbon black untuk bahan HDPE kuat tariknya lebih tinggi bila dibandingkan dengan bahan LDPE maupun campuran dari LDPE dan HDPE. Menurut Brydson (1979), sifat mekanis polimer sangat tergantung dari berat molekul dan densitas polimer tersebut. Berat molekul dan densitas makin tinggi maka kuat tarik akan makin tinggi dan polimer tersebut makin rapuh. Hal ini sesuai dengan hasil uji plastik untuk irigasi sistem tetes dengan bahan HDPE 100 bagian mempunyai nilai kuat tarik tertinggi. Tetapi setelah dilakukan uji foto cle gradasi dengan sinar ultraviolet selama 5 hari dan 10 hari maka plastik tersebut menjadi rapuh. Sedangkan plastik dengan bahan LDPE 100 bagian setelah dilakukan uji foto degradasi selama 5 dan 10 hari masih baik dan mempunyai nilai kuat tarik sebesar $16,81 \mathrm{~kg} / \mathrm{cm} 2 \mathrm{dan} 6,28 \mathrm{~kg} / \mathrm{cm}^{2}$. Plastik dengan bahan campuran LDPE 50 bagian dan HDPE 50 bagian mempunyai nilai kuat tarik diatas LDPE dan dibawah HDPE yaitu sebesar $178,235 \mathrm{~kg} / \mathrm{cm}^{2}$. Plastik dapat diperbaiki sifat fisisnya dengan menambahkan bahian pengisi, aditif dan bahan penguat. Menurut Katz dan Milewski (1978), penambahan carbon black pada plastik dapat berfungsi sebagai bahan pengisi selain itu dapat mencegah kerapuhan karena adanya perubahan cuaca. Dari hasil uji semakin banyak carbon black yang ditambahkan pada pembuatan plastik untuk irigasi sistem tetes dengan bahan baku HDPE, LDPE maupun campuran HDPE dan LDPE kuat tarik makin menurun, plastik dengan bahan HDPE 100 bagian dengan carbon black 2,5 bagian, 5 bagian, 7,5 bagian dan 10 bagian masing-masing mempunyai kuat tarik $239,39 \mathrm{~kg} / \mathrm{cm}^{2}, 221,68 \mathrm{~kg} / \mathrm{cm}^{2}, 216,33 \mathrm{~kg} / \mathrm{cm}^{2}$ dan $158,02 \mathrm{~kg} / \mathrm{cm}^{2}$, dan sifat fisis masih memenuhi SNI 19-4377-1996 yang ditetapkan sebesar $120 \mathrm{~kg} / \mathrm{cm}^{2}$. Hal ini disebabkan carbon black berfungsi sebagai filler (bahan pengisi) yang bersifat non adherent yaitu bila bahan pengisi tersebut ditambahkan ke bahan plastik maka selama proses orientasi polimernya akan memisah dari pengisi membentuk microvoid sehingga terbentuk struktur mikroporous yang mengakibatkan penurunan kuat tarik (Levy, 1977). Plastik dilakukan uji foto degradasi dengan melakukan penyinaran selama 5 dan 10 hari, setelah itu dilakukan pengujian kuat tarik. Hasil menunjukkán makin banyak carbon black yang ditambahkan makin tahan terhadap sinar ultraviolet. Hal ini ditunjukan oleh plastik dengan bahan HDPE 100 bagian menggunakan carbon black 10 bagian, dimana plastik tersebut tidak rapuh hingga lama penyinaran 10 hari, ditunjukkan dengan nilai kuat tarik sebesar $56,58 \mathrm{~kg} / \mathrm{cm}^{2}$ dengan prosentase penurunan sebesar $64,20 \%$. Sedangkan plastik untuk bahan LDPE 100 bagian dan campuran LDPE 50 bagian dan HDPE 50 bagian pada lama penyinaran 10 hari sudah rapuh. Dengan demikian plastik dengan bahan HDPE 100 bagian dan carbon black 10 bagian lebih tahan terhadap penyinaran. 
Tabel 4. Hasil uji kemuluran plastik untuk irigasi sistem tetes

\begin{tabular}{|c|c|c|c|c|c|c|c|c|c|}
\hline \multirow{4}{*}{$\begin{array}{l}\text { Carbon } \\
\text { black } \\
\text { (bagian) }\end{array}$} & \multicolumn{9}{|c|}{ Kemuluran (\%) } \\
\hline & \multicolumn{3}{|c|}{ LDPE/HDPE $=0 / 100$} & \multicolumn{3}{|c|}{ LDPE/HDPE $=100 / 0$} & \multicolumn{3}{|c|}{ LDPE $/ \mathrm{HDPE}=50 / 50$} \\
\hline & \multirow{2}{*}{$\begin{array}{l}\text { Sebelum } \\
\text { Penyinaran } \\
\text { UV }\end{array}$} & \multicolumn{2}{|c|}{$\begin{array}{c}\text { Sesudah } \\
\text { Penyinaran UV }\end{array}$} & \multirow{2}{*}{$\begin{array}{c}\text { Sebelum } \\
\text { Penyinaran } \\
\text { UV }\end{array}$} & \multicolumn{2}{|c|}{$\begin{array}{c}\text { Sesudah } \\
\text { Penyinaran UV }\end{array}$} & \multirow{2}{*}{$\begin{array}{l}\text { Sebelum } \\
\text { Penyinaran } \\
\text { UV }\end{array}$} & \multicolumn{2}{|c|}{$\begin{array}{c}\text { Sesudah } \\
\text { Penyinaran UV }\end{array}$} \\
\hline & & 5 hari & 10 hari & & 5 hari & 10 hari & & 5 hari & 10 hari \\
\hline 0 & 371,67 & 2,30 & 0 & 280,83 & 4,97 & 0 & 300,00 & 5,67 & 0 \\
\hline 2,5 & 247,50 & 7,23 & 0 & 191,67 & 10,00 & 0 & 241,67 & 10,0 & 0 \\
\hline 5,0 & 225,00 & 11,16 & 0 & 188,75 & 13,33 & 0 & 235,00 & 10,0 & 0 \\
\hline 7,5 & 211,17 & 11,32 & 0 & 176,67 & 16,08 & 0 & 195,00 & 10,0 & 0 \\
\hline 10 & 140,0 & 57,93 & 48,27 & 147,67 & 17,50 & 0 & 176,67 & 10,0 & 0 \\
\hline
\end{tabular}

Kemuluran menurut SNI 19-4377-1996 "Plastik Polietilen untuk mengemas min $125 \%$

Tabel. 5 prosentase penurunan kemuluran sesudah penyinaran

\begin{tabular}{|l|c|c|c|c|c|c|}
\hline \multirow{2}{*}{$\begin{array}{l}\text { Carbon } \\
\text { black }\end{array}$} & \multicolumn{6}{|c|}{$\Delta$ Kemuluran $(\%)$} \\
\cline { 2 - 7 } (bagian) & \multicolumn{2}{|c|}{ LDPE/HDPE $=0 / 100$} & \multicolumn{2}{c|}{ LDPE/HDPE $=100 / 0$} & \multicolumn{2}{c|}{ LDPE/HDPE $=50 / 50$} \\
\cline { 2 - 7 } & 5 hari & 10 hari & 5 hari & 10 hari & 5 hari & 10 hari \\
\hline 0 & 99,38 & 100 & 98,33 & 100 & 98,11 & 100 \\
2,5 & 97,08 & 100 & 94,78 & 100 & 95,86 & 100 \\
5,0 & 95,04 & 100 & 92,94 & 100 & 95,75 & 100 \\
7,5 & 94,64 & 100 & 90,09 & 100 & 94,70 & 100 \\
10,0 & 58,62 & 65,62 & 88,15 & 80,41 & 94,34 & 100 \\
\hline
\end{tabular}

2. Kemuluran

Dari hasil pengujian kemuluran yang terdapat pada tabel 4 dan 5 dapat dikemukakan semakin banyak penambahan filler carbon black, nilai kemuluran semakin menurun, hal ini disebabkan dengan bertambahnya filler carbon black maka akan terbentuk ikatan antar molekul antara plastik dan carbon black yang akan menyebabkan berkurangnya gerakan dari polimer sehingga elastisitasnya juga menurun. Besarnya angka kemuluran untuk plastik dengan bahan baku HDPE, LDPE serta campuran HDPE \& LDPE penambahan carbon black sampai dengan 10 bagian masih memenuhi persyaratan SNI 19-4377-1996 yang ditetapkan sebesar $125 \%$. Tetapi setelah plastik tersebut dilakukan pengujian foto degradasi dengan sinar ultra violet nilai kemuluran mengalami penurunan, bahkan ada beberapa plastik rapuh setelah disinari selama 10 hari. Plastik dengan bahan HDPE 100 bagian, carbon black 10 bagian adalah yang terbaik sebab sebelum penyinaran mempunyai nilai kemuluran memenuhi persyaratan sedangkan sesudah penyinaran selama 10 hari mempunyai nilai penurunan prosentase kecil yaitu $48,27 \%$. Plastik dengan bahan campuran LDPE 50 bagian dan HDPE 50 bagian untuk penambahan carbon black mulai dari 2,5 bagian sampai dengan 10 bagian hanya tahan disinari sampai 5 hari, apabila penyinaran diteruskan sampai 10 hari maka plastik menjadi rapuh. 
Tabel. 6. Hasil uji kuat sobek plastik untụk irigasi sistem tetes

\begin{tabular}{|c|c|c|c|c|c|c|c|c|c|}
\hline \multirow{4}{*}{$\begin{array}{l}\text { Carbon } \\
\text { black } \\
\text { (bagian) }\end{array}$} & \multicolumn{9}{|c|}{ Kuat Sobek $(\mathrm{kg} / \mathrm{cm} 2)$} \\
\hline & \multicolumn{3}{|c|}{$\mathrm{LDPE} / \mathrm{HDPE}=0 / 100$} & \multicolumn{3}{|c|}{$\mathrm{LDPE} / \mathrm{HDPE}=100 / 0$} & \multicolumn{3}{|c|}{$\mathrm{LDPE} / \mathrm{HDPE}=50 / 50$} \\
\hline & \multirow{2}{*}{$\begin{array}{c}\text { Sebelum } \\
\text { Penyinaran } \\
\text { UV }\end{array}$} & \multicolumn{2}{|c|}{$\begin{array}{c}\text { Sesudah } \\
\text { Penyinaran UV }\end{array}$} & \multirow{2}{*}{$\begin{array}{c}\text { Sebelum } \\
\text { Penyinaran } \\
\text { UV }\end{array}$} & \multicolumn{2}{|c|}{$\begin{array}{c}\text { Sesudah } \\
\text { Penyinaran UV }\end{array}$} & \multirow{2}{*}{$\begin{array}{c}\text { Sebelum } \\
\text { Penyinaran } \\
\text { UV }\end{array}$} & \multicolumn{2}{|c|}{$\begin{array}{c}\text { Sesudah } \\
\text { Penyinaran UV }\end{array}$} \\
\hline & & 5 hari & 10 hari & & 5 hari & 10 hari & & 5 hari & 10 hari \\
\hline 0 & 126,51 & 0 & 0 & 76,08 & 6,88 & 3,57 & 165,74 & 15,41 & 0 \\
\hline 2.5 & 113,58 & 0 & 0 & 73,30 & 12,87 & 6,90 & 156,06 & 16,57 & 0 \\
\hline 5,0 & 109,72 & 0 & 0 & 68,66 & 18,55 & 10,28 & 125,00 & 13,42 & 0 \\
\hline 7.5 & 100,12 & 0 & 0 & 62,78 & 23,64 & 15,04 & 121,05 & 13,33 & 0 \\
\hline 10 & 91,46 & 58,80 & 56,58 & 62,54 & 23,68 & 18,09 & 100,54 & 11,46 & 0 \\
\hline
\end{tabular}

Kuat sobek menurut SNI 19-4377-1996 "Plastik Polietilen untuk mengemas" adalah $\min 70 \mathrm{~kg} / \mathrm{cm} 2$.

Tabel 7. Prosentase penurunan kuat sobek sesudah penyinaran dengan ultra violet

\begin{tabular}{|l|c|c|c|c|c|c|}
\hline \multirow{2}{*}{$\begin{array}{l}\text { Carbon } \\
\text { black }\end{array}$} & \multicolumn{9}{|c|}{$\Delta$ Kuat Sobek $(\%)$} \\
\cline { 2 - 7 } (bagian) & LDPE/HDPE $=0 / 100$ & \multicolumn{2}{c|}{ LDPE/HDPE $=100 / 0$} & \multicolumn{2}{|c|}{ LDPE/HDPE $=50 / 50$} \\
\cline { 2 - 7 } & 5 hari & 10 hari & 5 hari & 10 hari & 5 hari & 10 hari \\
\hline 0 & 86,06 & 100 & 90,96 & 95,31 & 90,70 & 100 \\
2,5 & 83,07 & 100 & 82,44 & 90,39 & 89,38 & 100 \\
5,0 & 80,10 & 100 & 72,99 & 85,03 & 89,36 & 100 \\
7,5 & 78,07 & 100 & 62,34 & 76,04 & 89,00 & 100 \\
10,0 & 35,70 & 38,13 & 62,13 & 71,08 & 88,60 & 100 \\
\hline
\end{tabular}

3. Kuat Sobek

Hasil uji kuat sobek yang tertera di dalam tabel 6 dan 7 menunjukkan bahwa untuk plastik dengan bahan baku HDPE 100 bagian dan LDPE 100 bagian, penambahan carbon black cenderung menurunkan sifat kuat sobek. Hal ini disebabkan karakteristik suatu kompon tergantung dari interaksi antara carbon black dan polimer. Mudah tidaknya interaksi tersebut tergantung dari struktur molekul bahan pengisi. Untuk struktur molekul agregate (bergerombol) akan menghasilkan sifat berbeda dengan bahan pengisi yang berstruktur polyhidrol, hal ini menyebabkan kompon bersifat porous sehingga penambahan carbon black nilai kuat sobek turun. Nilai kuat sobek plastik dengan bahan baku HDPE 100 bagian, campuran HDPE 50 bagian dan LDPE 50 bagian semua memenuhi persyaratan SNI 19-4377-1996, yang dipersyaratkan sebesar $70 \mathrm{~kg} / \mathrm{cm} 2$. Untuk plastik dengan bahan baku LDPE 100 bagian hanya ada 1 formulasi yang memenuhi persyaratan yaitu LDPE 100 bagian, carbon black 2,5 bagian dimana nilai kuat sobeknya sebesar 73,30 kg/ $\mathrm{cm} 2$. Nilai kuat sobek mengalami penurunan setelah dilakukan uji foto degradasi dengan sinar ultraviolet. Makin besar carbon black yang ditambahkan ada kecenderungan prosentase penurunan semakin kecil. Prosentase penurunan yang terkecil terjadi pada plastik dengan bahan baku HDPE 100 bagian dan carbon black 10 bagian dimana prosentase penurunannya sesudah 5 hari dan 10 hari adalah sebesar $35,70 \%$ dan $38,13 \%$ yang merupakan plastik untuk irigasi sistem tetes yang terbaik. 


\section{KESIMPULAN}

1. Makin banyak jumlah carbon black yang ditambahkan pada pembuatan plastik untuk irigasi sistem tetes akan menurunkan nilai kuat tarik, kemuluran, kuat sobek dan plastik untuk irigasi sistem tetes dengan bahan baku HDPE 100 bagian, LDPE 100 bagian dan campuran LDPE 50 bagian HDPE 50 bagian sampai dengan penambahan carbon black 10 bagian, ketiga sifat fisis yang diuji masih memenuhi SNI 19-4377-1996, Plastik polietilena
untuk mengemas.

2. Carbon black berfungsi sebagai bahan pengisi pada pembuatan plastik untuk irigasi sistem tetes dan memberikan pengaruh pencegahan kerapuhan akibat sinar ultra violet dan penambahan carbon black 10 bagian pada bahan HDPE mampu mencegah kerapuhan plastik untuk irigasi sistem tetes setelah disinari dengan ultra violet selama 10 hari.

3. Formulasi plastik untuk irigasi tetes adalah HDPE 100 bagian, carbon black 10 bagian, asam stearat 5 bagian dan tin stabilizer 1 bagian.

\section{DAFTAR PUSTAKA} Anonim, 1996, Dewan Standardisasi Nasional, SNI 19-4377-1996 "Plastik Polietilena untuk
Mengemas".

Brydson, J.A., 1970, Plastics Materials, Buffer Worth and Co, Ltd, London.

Davis and Davis Sims, 1983, Wheatering of Polymers, Applied Science Publishers, London and New York.

Fisher, E.G., 1976, Extrusion of Plastics, Plastics Rubber Institute, London, pp 310 - 316.

Howell, T. A., Stevenson, D.S., Aljibury, F.K., Grithin, P.A., Wu, I. P., Warrick, A.W. and Roats, P.A.C., 1983, Design and Operation of trickle (drip) System. In Design and Operation of Form Irigation System (M.F. Jensen, edı), Manager 3, pp 663 - 717.

Katz, H.S., Milewski, J.V., 1978, Hand book of Fillers and Reinforcements for Plastics, Van Nostrand Reinhold Company, London, pp $47-52$.

Levy, S., 1977, Plastics Product Design Engineering Hand Book, Van Nostrand Reinhold, New York, pp 43 - 58

Phene, C. J. and Phene, R.C., 1987, Drip Irigation Systems and Managemen, Extension Bulletin No. 244, PVC 1 - 24, January.

Samuel, S., Oloesky., 1964, Hand Book of Reinforced Plastics, Van Nostrand Reinhold Co., New York. 